\title{
EXOGENOUS NITRIC OXIDE DONOR SODIUM NITROPRUSSIDE ENHANCED GROWTH ATTRIBUTES OF POLYBAGGED RUBBER (Hevea brasiliensis ) SEEDLINGS
}

\author{
NMC Nayanakantha $^{1 *}$, NN Hettiarachchi ${ }^{2}$, P Seneviratne $^{1}$ and DL Wathugala ${ }^{2}$ \\ ${ }^{1}$ Rubber Research Institute, Dartonfield, Agalawatta, Sri Lanka \\ ${ }^{2}$ Department of Crop Science, Faculty of Agriculture, University of Ruhuna, Mapalna, Kambu- \\ rupitiya, Sri Lanka
}

Accepted: $30^{\text {th }}$ November 2016

\begin{abstract}
Shoot die-back condition has been observed in young-budded rubber plants especially under hot and dry weather conditions. This is partly attributed failure of the root system. Therefore, it is imperative to find ways to improve the root system while enhancing other growth attributes of polybagged rubber seedlings. Nitric oxide (NO) functions as a signaling molecule as well as a phytohormone in numerous physiological processes in plants from seed germination up to senescence. In the present study, the effect of sodium nitroprusside (SNP) as a NO donor on the root architecture and growth characteristics of polybagged rubber seedlings were investigated. Seven days old rubber seedlings were soaked in $200 \mu \mathrm{M}$ and $500 \mu \mathrm{M}$ solutions of SNP for 6 hours and 24 hours respectively prior to transplanting in polybags. Mock treated seedlings were soaked in water. Pretreatment with SNP greatly improved the root architecture of rubber seedlings by increasing the number and the length of lateral roots and the dry weight of roots while enhancing other growth parameters viz., stem diameter, shoot height and dry weight, leaf area and chlorophyll content in dose and time-dependant manner. Pretreatment with SNP at 500 $\mu$ M for 6 hrs was found to be more effective for overall growth improvement in rubber seedlings. The improved growth characteristics of rubber seedlings could be attributed to the beneficial effect of SNP as a NO donor in modifying phytohormone signalling pathways, enhancing antioxidant enzyme activity, increase in nutrient uptake and effective allocation of photoassimilates.
\end{abstract}

Key words: Concentration, Growth, Nitric oxide, Phytohormones, Rubber, Sodium nitroprusside

\section{INTRODUCTION}

Rubber (Hevea brasiliensis) is an important tree crop producing latex for commercial utility. The standard practice adopted in the commercial propagation of rubber clones is by grafting buds of selected clones on to unselected seedling rootstocks raised in polybags using young budding technique. Shoot die back condition has been observed in youngbudded rubber plants under hot and dry weather conditions in the recent past, partly due to failure of the root system at high temperature (Dharmakeerthi et al., 2008). Therefore, it is essential to find ways to improve root architecture of rubber seedlings while enhancing other growth attributes to perform well under stressful conditions.

Root system of a plant is the site of water and nu-trients uptake, a sensor of biotic and abiotic

*Corresponding author: nayanakanthachamil7@gmail.com stress, a structural anchor to support the whole plant, and the storage organ in some species. In the development of plant root system architecture (RSA), the initiation and development of lateral (secondary) roots (LRs) is the most important event. The length of the primary root (PR, tap root), the density of lateral roots and development of root hairs determine the architecture of the root system, and this, in turn, plays a major role in determining whether a plant will succeed in a particular environment (Malamy and Benfey, 1997).

The gaseous free radical nitric oxide (NO) has recently gained special interest in the research community given its involvement in a number of signaling cascades controlling plant responses ranging from seed germination to plant senescence (Freschi, 2013; Kong et al., 2014; Mur et al., 2012). Nitric oxide is required for root organogenesis (Pagnussat et 
al., 2002), formation of adventitious roots (Pagnussat et al., 2003), lateral root development (Correa-Aragunde et al., 2004) and root hair formation (Pagnussat et al., 2002). Nitric oxide has also been identified as the key player in regulating signaling pathways responsible for biotic and abiotic stress tolerance in crop plants (Mur et al., 2012). Under stressful conditions, plants accumulate a substantial level of NO to alleviate the oxidative stress exerted due to various stresses (Cui et al., 2011).

The most commonly used NO donor in previous studies is sodium nitroprusside (SNP), because it gives a continuous and a long-lasting NO production compared to other NO donors (Correa-Aragunde et al., 2004). Accumulated evidence indicates that the effects of NO can deeply differ according to the concentration of donor used. For example, applications of high levels of NO have been shown to inhibit plant growth but the application of low levels can promote it (Parani, 2004). In addition, it is accepted that high NO donor concentrations may induce detoxification responses while lower concentrations might more accurately reflect its role as a signalling molecule (Wink and Mitchel, 1998; Beligni and Lamattina, 1999). Nayanakantha et al. (2014) demonstrated that application of $50 \mathrm{ml}$ of SNP (at $50-500 \mu \mathrm{M}$ ) into polybagged rubber seedlings greatly improved the root and growth characteristics under glass house conditions.

In view of this, present study aimed at investigating the pretreatment effect of SNP on root architecture and growth characteristics of polybagged rubber seedlings under nursery conditions. We report here that, pretreatment with SNP, in dose-and time dependent manner, ameliorates the root architecture and growth characteristics of rubber seedlings.

\section{MATERIALS AND METHODS}

\section{Planting material}

The study was conducted in a nursery at the Dartonfield estate of the Rubber Research In- stitute of Sri Lanka (RRISL). Seeds were collected from the clone RRIC 100, sown in a germination bed filled with sand. Black polythene bag, gauge 300 and having lay-flat dimensions of $15 \mathrm{~cm}$ diameter and $37 \mathrm{~cm}$ height, filled with soil collected from the Agalawatta series from the surface layer $(0-15 \mathrm{~cm}$ depth) were used. The soils were sieved through a 1 $\mathrm{cm}$ mesh to remove large lateritic gravel before filling the bags and filling of polybags was done as recommended by the Rubber Research Institute of Sri Lanka.

\section{Pretreatments with SNP}

Nitric Oxide donor sodium nitroprusside was purchased from sigma, (MO, USA). One week old rubber seedlings were imposed with seven treatments as listed in Table 1.

\begin{tabular}{ll}
\multicolumn{2}{l}{$\begin{array}{l}\text { Table 1: Treatments imposed for rubber } \\
\text { seedlings in the present study }\end{array}$} \\
\hline Treatment & Content \\
\hline T1 & Control (without soaking) \\
T2 & Soaked in water for 6 hours \\
T3 & Soaked in water for 24 hours \\
T4 & $\begin{array}{l}\text { Soaked in } 200 \mu \mathrm{mol} \text { SNP for } 6 \\
\text { hours }\end{array}$ \\
T5 & $\begin{array}{l}\text { Soaked in } 200 \mu \mathrm{mol} \text { SNP for } 24 \\
\text { hours }\end{array}$ \\
T6 & $\begin{array}{l}\text { Soaked in } 500 \mu \mathrm{mol} \text { SNP for } 6 \\
\text { hours }\end{array}$ \\
T7 & $\begin{array}{l}\text { Soaked in } 500 \mu \mathrm{mol} \text { SNP for } 24 \\
\text { hours }\end{array}$ \\
\hline
\end{tabular}

\section{Growing of rubber seedlings}

Polybags were arranged in a randomized complete block design (RCBD) in the nursery. Each treatment had 32 individual plant replicates (polybags) arranged in 4 blocks. In each block, there were 56 polybags, 8 from each treatment. Each seedling was supplied with 100 $\mathrm{ml}$ of water once daily. Two weeks after transplanting, application of chemical fertilizers, i.e. young-budding fertilizer mixture in liquid form, in to seedlings was started and carried out at two-week intervals. All other agro management practices were done as recommended by the Rubber Research Institute of Sri Lanka (Anon, 2009). 


\section{Measurement of growth parameters}

The morphological and physiological attributes, viz. diameter of stem, plant height, number of leaves, leaf area, total chlorophyll content, dry weight (DW) of shoots, PR and LRs were recorded after 12 weeks from transplanting. Ten plants from each treatment were selected randomly and root system was washed gently under running tap water over a $0.5 \mathrm{~mm}$ sieve and adhering soil particles were carefully removed. Diameter of stem was taken using a digital vernior caliper (one centimeter above the collar region). Plant height was taken using a measuring tape. Leaf area was measured by using a Digital Leaf Area Meter (Model L1-3100, LICOR, USA). Chlorophyll content was measured using SPAD 502 Plus chlorophyll meter. Shoots and roots were dried in an oven at $70{ }^{\circ} \mathrm{C}$ for $6-7$ hours and weighted using an electronic balance.

\section{Statistical analysis of data}

Significance of the observed treatment differences were tested by analysis of variance using proc GLM procedure of the SAS software package (Version 9.1) and means were separated using the Duncan's Multiple Range Test $(\mathrm{DMRT})$ at $\mathrm{p} \leq 0.05$.

\section{RESULTS}

\section{Shoot characteristics}

Pretreatment of rubber seedlings with NO donor SNP significantly $(\mathrm{p} \leq 0.05)$ improved growth characteristics viz., stem diameter, height of stem, leaf area, chlorophyll content, DW of shoots and root characteristics in dose and time-dependent manner as compared to control and mock treatments after 12 weeks from transplanting into poly bags (Table 2-3). Neither abnormalities nor phytotoxicity symptoms were observed in rubber seedlings pretreated with SNP at both concentrations and time intervals for any of the morphological attributes.

There was a significant difference in plant height among treatments as compared to control and tallest plants were produced with SNP pretreatment at $500 \mu \mathrm{M}$ for $6 \mathrm{hrs}$ followed by $200 \mu \mathrm{M}$ for $6 \mathrm{hrs}$ (Table $2 \& 3$ ). Nevertheless, mock treatments were also resulted in significantly $(\mathrm{p} \leq 0.05)$ higher stem diameter as compared to control (Table 2$)$. A significantly $(p \leq$ 0.05 ) higher stem diameter and shoot DW was recorded from the seedlings pretreated with SNP at $500 \mu \mathrm{M}$ for $6 \mathrm{hrs}$ as compared to other treatments and the control (Table 2). Neither SNP treatments nor mock treatments in-

Table 2: Effect of SNP pretreatment on shoot characteristics of rubber seedlings after12 weeks from transplanting into poly bags.

\begin{tabular}{lllll}
\hline Treatment & $\begin{array}{l}\text { Stem height } \\
\text { (cm/plant) }\end{array}$ & $\begin{array}{l}\text { Stem diameter } \\
\text { (mm/plant) }\end{array}$ & $\begin{array}{l}\text { Internodel } \\
\text { Length } \\
\text { (cm/plant) }\end{array}$ & $\begin{array}{l}\text { DW of shoot } \\
\text { ( g/ plant) }\end{array}$ \\
\hline T1 & $55.9 \pm 1.34^{\mathrm{d}}$ & $6.31 \pm 0.18^{\mathrm{c}}$ & $13.3 \pm 1.28^{\mathrm{ab}}$ & $7.30 \pm 0.41^{\mathrm{d}}$ \\
T2 & $60.7 \pm 2.78^{\mathrm{abc}}$ & $7.33 \pm 0.20^{\mathrm{bc}}$ & $14.6 \pm 1.24^{\mathrm{a}}$ & $10.50 \pm 1.03^{\mathrm{bc}}$ \\
T3 & $58.0 \pm 2.46^{\mathrm{c}}$ & $6.72 \pm 0.20^{\mathrm{c}}$ & $11.7 \pm 1.01^{\mathrm{b}}$ & $8.73 \pm 0.80^{\mathrm{cd}}$ \\
T4 & $66.0 \pm 2.50^{\mathrm{a}}$ & $7.71 \pm 0.31^{\mathrm{b}}$ & $14.1 \pm 0.74^{\mathrm{a}}$ & $11.07 \pm 1.03^{\mathrm{b}}$ \\
T5 & $59.1 \pm 0.71^{\mathrm{bc}}$ & $7.61 \pm 0.23^{\mathrm{b}}$ & $13.3 \pm 0.37^{\mathrm{ab}}$ & $10.13 \pm 0.64^{\mathrm{bc}}$ \\
T6 & $67.2 \pm 3.51^{\mathrm{a}}$ & $8.35 \pm 0.12^{\mathrm{a}}$ & $15.4 \pm 0.82^{\mathrm{a}}$ & $13.75 \pm 0.63^{\mathrm{a}}$ \\
T7 & $60.4 \pm 1.50^{\mathrm{abc}}$ & $7.30 \pm 0.20^{\mathrm{bc}}$ & $14.5 \pm 0.81^{\mathrm{a}}$ & $8.62 \pm 0.48^{\mathrm{cd}}$ \\
\hline
\end{tabular}

The values are means and SE of 10 seedlings $(n=10)$. Letters indicate significant difference at $\mathrm{p} \leq 0.05$ according to DMRT. Values followed by the same letter in a column are not significantly different at $\mathrm{p} \leq 0.05$. 
creased the intermodal length significantly as compared to control (Table 2). SNP treatment at $500 \mu \mathrm{M}$ for $6 \mathrm{hrs}$ significantly $(\mathrm{p} \leq 0.05)$ increased the number of leaves, chlorophyll content and the leaf area as compared to mock treatments and the control (Table 3).

\section{Root characteristics}

Root characteristics viz., number of early secondary roots (ESR) and secondary roots (SR), length of ESR, SR, tap root and DW of roots were significantly improved with SNP pretreatments as compared to mock treatments and the control and after 12 weeks from trans- planting into poly bags (Table $4 \& 5$ ). There was no significant difference in the number of ESR in response to SNP or mock treatments as compared to control (Table 4). However, length of ESR increased significantly $(\mathrm{p} \leq$ 0.05 ) in response to SNP treatments at both concentrations $(200 \mu \mathrm{M} \& 500 \mu \mathrm{M})$ and time durations (6 hrs \& $24 \mathrm{hrs}$ ) as compared to mock treatments and the control (Table 4).

Number of SR increased significantly in response to SNP treatments and mock treatments for both time durations as compared to control (Table 4). Nevertheless, length of SR

Table 3: Effect of SNP pretreatment on shoot characteristics of rubber seedlings after12 weeks from transplanting into poly bags.

\begin{tabular}{llll}
\hline Treatment & $\begin{array}{l}\text { No. of leaves } \\
\text { (per plant) }\end{array}$ & $\begin{array}{l}\text { Chlorophyll content/plant } \\
\text { (SPAD value) }\end{array}$ & $\begin{array}{l}\text { Leaf Area } \\
\left.\text { (cm }^{2} / \mathbf{p l a n t}\right)\end{array}$ \\
\hline T1 & $9.2 \pm 0.48^{\mathrm{b}}$ & $48.87 \pm 2.38^{\mathrm{c}}$ & $521.85 \pm 60.53^{\mathrm{c}}$ \\
T2 & $9.8 \pm 0.58^{\mathrm{b}}$ & $46.20 \pm 1.54^{\text {cd }}$ & $787.75 \pm 91.21^{\mathrm{b}}$ \\
T3 & $8.8 \pm 0.37^{\mathrm{b}}$ & $44.96 \pm 0.67^{\mathrm{d}}$ & $488.90 \pm 72.80^{\mathrm{c}}$ \\
T4 & $9.2 \pm 0.48^{\mathrm{b}}$ & $53.13 \pm 0.45^{\mathrm{b}}$ & $798.43 \pm 91.12^{\mathrm{b}}$ \\
T5 & $8.8 \pm 0.20^{\mathrm{b}}$ & $52.80 \pm 1.63^{\mathrm{b}}$ & $710.11 \pm 45.99^{\mathrm{b}}$ \\
T6 & $11.2 \pm 0.58^{\mathrm{a}}$ & $61.09 \pm 1.03^{\mathrm{a}}$ & $1199.49 \pm 88.85^{\mathrm{a}}$ \\
T7 & $9.4 \pm 0.4^{\mathrm{b}}$ & $54.90 \pm 1.13^{\text {ab }}$ & $787.39 \pm 58.51^{\mathrm{b}}$ \\
\hline
\end{tabular}

The values are means and SE of 10 seedlings $(n=10)$. Letters indicate significant difference at $\mathrm{p} \leq 0.05$ according to DMRT. Values followed by the same letter in a column are not significantly different at $\mathrm{p} \leq 0.05$.

Table 4: Effect of SNP pretreatment on shoot characteristics of rubber seedlings after12 weeks from transplanting into poly bags.

\begin{tabular}{llllll}
\hline $\begin{array}{l}\text { Treat } \\
\text { ment }\end{array}$ & $\begin{array}{l}\text { No. of ESR } \\
\text { /plant }\end{array}$ & $\begin{array}{l}\text { No. of SR } \\
\text { /plant }\end{array}$ & $\begin{array}{l}\text { Length of } \\
\text { ESR } \\
\text { (cm/plant) }\end{array}$ & $\begin{array}{l}\text { Length of SR } \\
\text { (cm/plant) }\end{array}$ & $\begin{array}{l}\text { Length of } \\
\text { tap root } \\
\text { (cm/plant) }\end{array}$ \\
\hline T1 & $10.8 \pm 0.48^{\mathrm{a}}$ & $31.8 \pm 2.98^{\mathrm{c}}$ & $102.4 \pm 14.11^{\mathrm{c}}$ & $338.2 \pm 29.33^{\mathrm{c}}$ & $26.4 \pm 1.53^{\mathrm{c}}$ \\
$\mathrm{T} 2$ & $10.8 \pm 0.58^{\mathrm{a}}$ & $41.8 \pm 6.18^{\mathrm{ab}}$ & $97.8 \pm 15.98^{\mathrm{c}}$ & $379.4 \pm 42.10^{\mathrm{c}}$ & $28.3 \pm 1.54^{\mathrm{bc}}$ \\
$\mathrm{T} 3$ & $11.0 \pm 1.09^{\mathrm{a}}$ & $35.6 \pm 5.25^{\mathrm{b}}$ & $98.2 \pm 11.8^{\mathrm{c}}$ & $351.6 \pm 41.70^{\mathrm{c}}$ & $26.0 \pm 1.49^{\mathrm{c}}$ \\
T4 & $11.6 \pm 0.24^{\mathrm{a}}$ & $45.2 \pm 3.65^{\mathrm{ab}}$ & $144.2 \pm 18.2^{\mathrm{b}}$ & $653.3 \pm 45.90^{\mathrm{b}}$ & $35.5 \pm 0.74^{\mathrm{a}}$ \\
$\mathrm{T} 5$ & $12.6 \pm 1.20^{\mathrm{a}}$ & $46.8 \pm 6.05^{\mathrm{ab}}$ & $150.1 \pm 13.6^{\mathrm{b}}$ & $674 \pm 4.48^{\mathrm{b}}$ & $30.7 \pm 1.62^{\mathrm{ab}}$ \\
T6 & $13.8 \pm 1.52^{\mathrm{a}}$ & $56.8 \pm 8.43^{\mathrm{a}}$ & $214.0 \pm 19^{\mathrm{a}}$ & $816.2 \pm 47.55^{\mathrm{a}}$ & $34.5 \pm 2.03^{\mathrm{a}}$ \\
T7 & $11.8 \pm 1.28^{\mathrm{a}}$ & $49.4 \pm 3.74^{\mathrm{ab}}$ & $144.9 \pm 13.2^{\mathrm{b}}$ & $597.3 \pm 48.56^{\mathrm{bc}}$ & $31.4 \pm 1.06^{\mathrm{ab}}$ \\
\hline
\end{tabular}

The values are means and SE of 10 seedlings $(n=10)$. Letters indicate significant difference at $\mathrm{p} \leq 0.05$ according to DMRT. Values followed by the same letter in a column are not significantly different at $p \leq 0.05$. 
increased significantly in response to SNP treatment at $200 \mu \mathrm{M}$ for both time durations and $500 \mu \mathrm{M}$ for $6 \mathrm{hrs}$ as compared to mock treatments and the control (Table 4). Length of the tap root increased significantly in response to SNP treatments at both concentrations but only for $6 \mathrm{hrs}$ duration as compared to mock treatments and the control. However, DW of ESR and SR increased significantly only when seedlings were soaked in SNP solution at $500 \mu \mathrm{M}$ for $6 \mathrm{hrs}$ as compared to other treatments and the control (Table 5). Dry weight of tap root also increased in response to SNP treatments at both concentrations but only for $6 \mathrm{hrs}$ duration as compared to other treatments and the control (Table 5). Nevertheless, total DW of roots increased significantly when the seedlings were soaked in SNP solution at $500 \mu \mathrm{M}$ for $6 \mathrm{hrs}$ as compared to other treatments and the control (Table 5).

\section{DISCUSSION}

Roots are the plant organs that ensure nutrient and water supply for the whole organism. For this purpose root architecture has to be adapted to environmental conditions, including the development of root hairs and lateral roots (Thaler and Pages, 1996). Root system architecture has proved to be a critical factor in plant survival, contributing to water and nutrient acquisition efficiency and competitive fitness in a given environment. (Thaler and Pages, 1996).

Poly bagged rubber seedlings should possess a strong root system at the time of bud grafting, post bud grafting and field establishment stages. The plasticity to modulate the root architecture is one way to overcome the inability of plants to move towards water or nutrients stores. In this report, we present that pretreatment with NO donor SNP ameliorates two processes that define the root architecture of rubber seedlings: primary root growth and lateral root development.

In rubber seedlings, NO can modify the root architecture by increasing the number of secondary roots, branching of secondary roots and thereby increasing the number of feeder roots, lengths of secondary and feeder roots in a dose dependant manner and thus, enabling the seedlings for both horizontal and vertical exploration of nutrients within the poly bag. Typically, most of the roots found in poly bags show a rapid decline in both elongation rate and diameter and stop growing when the time of flushing, although some of them continue to grow thereafter (Le Roux and Pages, 1994; Thaler and Pages, 1996). This decrease

Table 5: Effect of SNP pretreatment on dry weight of roots of rubber seedlings after 12 weeks from transplanting into poly bags.

\begin{tabular}{lllll}
\hline Treatment & $\begin{array}{l}\text { DW of ESR } \\
\text { (g/plant) }\end{array}$ & $\begin{array}{l}\text { DW of SR } \\
\text { (g/plant) }\end{array}$ & $\begin{array}{l}\text { DW of taproot } \\
\text { (g/plant) }\end{array}$ & $\begin{array}{l}\text { Total DW } \\
\text { Roots } \\
\text { (g/plant) }\end{array}$ \\
\hline T1 & $0.44 \pm 0.07^{\mathrm{bc}}$ & $0.99 \pm 0.17^{\mathrm{c}}$ & $1.47 \pm 0.12^{\mathrm{b}}$ & $2.92 \pm 0.27^{\mathrm{c}}$ \\
$\mathrm{T} 2$ & $0.37 \pm 0.07^{\mathrm{bc}}$ & $1.11 \pm 0.18^{\mathrm{bc}}$ & $1.80 \pm 0.13^{\mathrm{b}}$ & $3.28 \pm 0.29^{\mathrm{bc}}$ \\
$\mathrm{T} 3$ & $0.35 \pm 0.05^{\mathrm{c}}$ & $0.75 \pm 0.10^{\mathrm{c}}$ & $1.58 \pm 0.13^{\mathrm{b}}$ & $2.70 \pm 0.22^{\mathrm{c}}$ \\
$\mathrm{T} 4$ & $0.61 \pm 0.04^{\mathrm{ab}}$ & $1.76 \pm 0.28^{\mathrm{ab}}$ & $2.40 \pm 0.47^{\mathrm{a}}$ & $4.68 \pm 0.73^{\mathrm{b}}$ \\
T5 & $0.63 \pm 0.07^{\mathrm{ab}}$ & $1.20 \pm 0.26^{\mathrm{bc}}$ & $1.70 \pm 0.24^{\mathrm{b}}$ & $3.45 \pm 0.49^{\mathrm{bc}}$ \\
T6 & $0.74 \pm 0.17^{\mathrm{a}}$ & $2.37 \pm 0.33^{\mathrm{a}}$ & $2.78 \pm 0.18^{\mathrm{a}}$ & $5.89 \pm 0.34^{\mathrm{a}}$ \\
T7 & $0.60 \pm 0.09^{\mathrm{ab}}$ & $1.01 \pm 0.02^{\mathrm{ab}}$ & $1.72 \pm 0.17^{\mathrm{b}}$ & $3.34 \pm 0.21^{\mathrm{bc}}$ \\
\hline
\end{tabular}

The values are means and SE of 10 seedlings $(n=10)$. Letters indicate significant difference at $\mathrm{p} \leq 0.05$ according to DMRT. Values followed by the same letter in a column are not significantly different at $\mathrm{p} \leq 0.05$. 
in root number has been interpreted in terms of enhanced competition for carbohydrates induced by the growth of the shoot (Thaler and Pages, 1996). Moreover, a rapid degradation of lateral and feeder roots has been observed 4-6 weeks after cut back from budgrafting, leading to a situation called "scion die back" in some plants under hot and dry weather conditions (Dharmakeerthi et al., 2008). Therefore, it could be hypothesized that the increase in number and length of lateral and feeder roots due to SNP pretreatment could alleviate the possible adverse effect exerted especially during post bud grafting period.

In recent years, nitric oxide (NO) has been recognized as an important endogenous signaling molecule that orchestrates multiple defense responses to both abiotic and biotic stresses (Mur et al., 2012). Studies conducted during the induction of diverse plant responses have demonstrated that NO may also affect biosynthesis, catabolism/conjugation, transport, perception, and/or transduction of almost all the phytohormones, i.e. auxins, gibberellins, cytokinins, abscisic acid (ABA), ethylene (ET), salicylic acid (SA), jasmonates, and brassinosteroids (BRs) (Freschi, 2013). During the signaling events leading to plant responses, NO frequently interacts with plant hormones and other endogenous molecules in complex signaling cascades (Freschi, 2013). Nitric oxide is rapidly induced by multiple hormonal and environmental stimuli, including ABA (Guo et al., 2003), hydrogen peroxide $\left(\mathrm{H}_{2} \mathrm{O}_{2}\right)$, polyamines (Tun et al., 2006), auxin, SA, BRs (Cui et al., 2011), drought, salt (Corpas et al., 2009), cold and heat (Zhao et al., 2009).

Synergistic effects of auxin and NO have been observed during the regulation of a series of plant responses, including the interplay between these molecules during adventitious roots formation (Pagnussat et al., 2004), lateral root development (Correa-Aragunde et al., 2004) and root hair initiation and elonga- tion (Lombardo et al., 2006). In virtually all of these cases, NO was identified to function downstream of auxins, apparently through linear signaling pathways.

Correa-Aragunde et al. (2004) showed that exogenous NO donor SNP at $200 \mu \mathrm{M}$ (as a whole plant spray-application) increased lateral root formation while reducing length of primary root in tomato seedlings. Our results demonstrated that pretreatment of rubber seedlings at $200 \& 500 \mu \mathrm{M}$ SNP solutions for $6 \mathrm{hrs}$ increased the number of lateral roots (ESR \& SR) and the length of ESR and SR but there was no reduction in primary root (tap root) growth as compared to control. Therefore, DW of ESR, SR, tap root and thereby total DW of roots increased significantly $(\mathrm{p} \leq 0.05)$ in response to SNP pretreatment as compared to control. Nevertheless, soaking of seedlings in water, especially for 24 hours, also improved some root and shoot attributes significantly as compared to control. This could be due to changes in the metabolic processes in response to water treatment, as has been reported in seeds during imbibition (Weitbrecht et al., 2011).

Apart from root characteristics, shoot characteristics also increased significantly $(\mathrm{p} \leq 0.05)$ due to SNP pretreatment in the present study. Leaf area increased significantly $(p \leq 0.05)$ with SNP pretreatment in a dose dependant manner. Chohan et al. (2012) demonstrated that in chick pea seedlings, leaf areas increased with exogenous SNP as a NO donor. This could be due to the cumulative effect of SNP through the regulation of exo-and endo- $\beta$ -D-glucanase in the cell wall. In the present study, SNP pretreated seedlings attained into buddable size (7-8mm) as compared to control within 3 months. This could be due to beneficial effect of NO in vegetative growth process of shoot, cell division and xylem differentiation (Zhang et al., 2003).

The improved characteristics of rubber seedlings could be due to the beneficial effect of 
SNP in plant signaling transduction through NO leading to favorable allocation of photoassimilates. Nitric oxide increases chlorophyll content in chick pea leaves, particularly in guard cells possibly by making iron availability (Chohan et al., 2012). Nitric oxide impacted transcription and/ or translation by regulating the expression of specific genes responsible for synthesis of enzymes determining chlorophyll biosynthesis.

\section{CONCLUSIONS}

Pretreatment with NO donor SNP, especially at $500 \mu \mathrm{M}$ for 6 hours, enhanced growth attributes and root architecture of rubber seedlings under nursery conditions, possibly by modifying phytohormone signaling pathways, enhancing antioxidant activity and increase in nutrient capturing process.

\section{ACKNOWLEDGEMENTS}

Statistical analysis done by Dr. (Mrs.) Wasana Wijesuriya of Rubber Research Institute is greatly acknowledged.

\section{REFERENCE}

Anon 2009 Production of budded plants. Advisory Circular. Rubber Research Institute of Sri Lanka.

Beligni MV and Lamattina L 1999 Nitric oxide protects against cellular damage produced by methylviologen herbicides in potato plants, Nitric Oxide 3: 199-208.

Chohan A, Parmar U and Raina SK 2012 Effect of Sodium nitroprusside on morphological characters under chilling stress in chickpea (Cicer arietinum L.). J. Environ. Biol. 33: 695-698.

Corpas FJ, Hayashi M, Mano S, Nishimura M and Barroso JB 2009 Peroxisomes are required for in vivo nitric oxide accumulation in the cytosol following salinity stress of Arabidopsis plants. Plant Physiol. 151: 2083-2094.

Correa-Aragunde N, Graziano M and Lamattina L 2004 Nitric oxide plays a central role in determining lateral root development in tomato. Planta 218: 900-905, doi: 10.1007/s00425-003-1172-7.

Cui JX, Zhou YH, Ding JG, Xia XJ, Shi K, Chen SC, Asami T, Chen Z and Yu JQ 2011 Role of nitric oxide in hydrogen peroxide-dependent induction of abiotic stress tolerance by brassinosteroids in cucumber. Plant Cell and Envi. 34: 347-358.

Dharmakeerthi RS, Senevirathna AMWK, Edirimanne VU and Chandrasiri JAS 2008 Effect of stock pruning on shoot and root growth of budded polybag plants of Hevea brasiliensis. Nat. Rub. Res. 21(1 \&2): 2431 .

Freschi L 2013 Nitric oxide and phytohormone interactions : current status and perspectives. Front. in Plant Sci. 4: 398, doi: 10.3389/fpls.2013.00398.

Guo FQ, Okamoto M, Crawford NM 2003 Identification of a plant nitric oxide synthase gene involved in hormonal signaling. Science 302: 100-103.

Kong J, Dong Y, Xu L, Liu S and Bai X 2014 Effects of foliar application of salicylic acid and nitric oxide in alleviating iron deficiency induced chlorosis of Arachis hypogaea L. Botanical Stud. 55(9): 1-9.

Le Roux Y, and Pages L 1994 Developpement et polymorphisme racinaires chez de jeunes semis d'hevea (Hevea brasiliensis). Canad. J. of Bot. 72: 924-32.

Lombardo MC, Graziano M, Polacco JC and Lamattina L 2006 Nitric oxide functions as a positive regulator of root hair development. Plant Sig. \& Behav. 1: 28-33. 
Malamy JE and Benfey PN 1997 Down and out in Arabidopsis: the formation of lateral roots. Trends Plant Sci. 2: 390-396.

Mur LAJ, Mandon J, Persijn S, Cristescu SM, Moshkov IE, Novikova GV, Hall MA, Harren FJM, Hebelstrup KH and Gupta KJ 2012 Nitric oxide in plants: an assessment of the current state of knowledge. AoB PLANTS 5. pls052; doi:10.1093/ aobpla/pls052.

Nayanakantha NMC, Pathirana PD, Senevirathna AMWK and Seneviratne P 2014 The effect of nitric oxide-donor sodium nitroprusside on root architecture and growth of young budding polybagged plants of rubber (Hevea brasiliensis). $5^{\text {th }}$ Symposium on Plantation Crop Research, Colombo. 77-90.

Pagnussat GC, Simontacchi M, Puntarulo S and Lamattina L 2002 Nitric oxide is required for root organogenesis. Plant Physiol. 129: 954-956.

Pagnussat GC, Lanteri ML and Lamattina L 2003 Nitric oxide and cyclic GMP are messengers in the indole acetic acid- induced adventitious rooting process. Plant Physiol. 132: 1241-1248. doi: 10.1104/ pp.103.022228.

Pagnussat GC, Lanteri ML, Lombardo MC and Lamattina L 2004 Nitric oxide mediates the indole acetic acid induction activation of a mitogen-activated protein kinase cascade involved in adventitious root development. Plant Physiol. 135: .279 -286. doi: 10.1104/pp.103.038554.

Parani M, Rudrabhatla S, Myers R, Weirich H, Smith B, Leaman DW and Goldman SL 2004 Microarray analysis of nitric oxide responsive transcripts in Arabidopsis, Plant Biotech. J. 2: 359-366.
Thaler P and Pages L 1996 Competition within the root system of rubber seedlings (Hevea brasiliensis) studied by root pruning and blockage. J. of Exp. Bot. 48(312): 1451-1459.

Tun NN, Santa-Catarina C, Begum T, Silveira V, Handro W, Floh EIS and Scherer GFE 2006 Polyamines induce rapid biosynthesis of nitric oxide (NO) in Arabidopsis thaliana seedlings. Plant Cell Physiol. 47 (3): 346-354.

Weitbrecht K, Muller K and Leubner-Metzger G 2011 First off the mark: early seed germination. J. of Expt. Bot. 62(10): 32893309.

Wink DA and Mitchell JB 1998 Chemical biology of nitric oxide: insights into regulatory, cytotoxic, and cytoprotective mechanisms of nitric oxide. Free Radic. Biol. Med. 25: 434-456.

Zhang ML, Feng AH, Chen T, Chen K, Liu Y, Tang H, Chang J and Wang X 2003. The cascade mechanisms of nitric oxide as a second messenger of ultraviolet B in inhibiting mesocotyl elongations. Photochem. \& Photobiol. 77: 219-225.

Zhao MG, Chen L, Zhang LL and Zhang WH 2009 Nitric reductase-dependent nitric oxide production is involved in cold acclimation and freezing tolerance in Arabidopsis. Plant Physiol. 151: 755-767. 